\title{
PEMBUATAN TEMPAT SAMPAH
}

\author{
EKA SERLI PRATIWI \\ 9173770410318 \\ ekaserlipratiwii@gmail.com
}

1. Bentuk kegiatan

$>$ Pembuatan tempat sampah.

2. Lokasi

$>$ Desa Bontocini

3. Hari/tanggal dan waktu

> Rabu, 30/09/2020 - 03/10/2020

4. Peserta yang di libatkan

> Mahasiswa KKLP YAPTI JENEPONTO

$>$ Karang taruna

5. Alasan diadakannya

> Alasan diadakannya kegiatan ini, karena melihat tidak ada tempat sampah umum Untuk menampung sampah-sampah yang ada di sepanjang jalan dan pekarangan rumah masyarakat.

6. Tujuan dan Manfaat

> Tujuan dan manfaat pembuatan tempat sampah ini untuk memudahkan masyarakat membuang sampah rumah tangganya. Agar tidak lagi membuangnya ke sembarang tempat.

7. Produk yang Dihasilkan

$>$ Tempat sampah sebanyak 6 buah.

8. Deskripsi Kegiatan

> Pembuatan tempat sampah ini dikerjakan selama 4 hari yaitu pada tanggal 30 September pengambilan bambu, 1 oktober pembersihan bambu, 2 oktober proses pembuatan tempat sampah, selesai pada tanggal 3 oktober dan dibagikan pada tanggal 8 oktober. 